2-15-1999

\title{
ATP Reception and Chemosensory Adaptation in Tetrahymena thermophila
}

\author{
M. Y. Kim \\ Heather G. Kuruvilla \\ CedarvilleUniversity, heatherkuruvilla@cedarville.edu \\ S. Raghu
}

T. M. Hennessey

Follow this and additional works at: http://digitalcommons.cedarville.edu/ science_and_mathematics_publications

Part of the Biology Commons

\section{Recommended Citation}

Kim, M. Y., Kuruvilla, H. G., Raghu, S., \& Hennessey, T. M. (1999). ATP reception and chemosensory adaptation in Tetrahymena thermophila. Journal of Experimental Biology, 202, 407-416.

This Article is brought to you for free and open access by DigitalCommons@Cedarville, a service of the Centennial Library. It has been accepted for inclusion in Science and Mathematics Faculty Publications by an authorized administrator of

DigitalCommons@Cedarville. For more information, please contact

digitalcommons@cedarville.edu. 


\title{
ATP RECEPTION AND CHEMOSENSORY ADAPTATION IN TETRAHYMENA
}

\section{THERMOPHILA}

\author{
M. Y. KIM ${ }^{1}$, H. G. KURUVILLA ${ }^{2}$, S. RAGHU ${ }^{1}$ AND T. M. HENNESSEY ${ }^{1, *}$ \\ ${ }^{1}$ Department of Biological Sciences, State University of New York at Buffalo, Buffalo, NY 14260, USA and \\ ${ }^{2}$ Department of Science and Mathematics, Cedarville College, PO Box 601, Cedarville, OH 45314, USA
}

*Author for correspondence (e-mail: Thennes@acsu.buffalo.edu)

Accepted 20 November 1998; published on WWW 21 January 1999

\begin{abstract}
Summary
Micromolar concentrations of adenosine triphosphate (ATP) and its non-hydrolyzable analog $\beta$ - $\gamma$-methylene ATP are both effective depolarizing chemorepellents in Tetrahymena thermophila. Chemorepellent behavior consists of repeated bouts of backward swimming (avoidance reactions) that can easily be quantified to provide a convenient bioassay for purinergic reception studies. Chemosensory adaptation occurs following prolonged exposure $(10 \mathrm{~min})$ to the repellents, and cells regain normal swimming behavior. Adaptation is specific since cells that are behaviorally adapted to either ATP or $\beta$ - $\gamma$-methylene ATP still retain full responsiveness to the chemorepellents GTP and lysozyme. However, cross adaptation occurs between ATP and $\beta$ - $\gamma$-methylene ATP, suggesting that they involve the same receptor. Behavioral sensitivity to both ATP and $\beta$ - $\gamma$-methylene ATP is increased by the addition of $\mathrm{Na}^{+}$, but addition of either $\mathrm{Ca}^{2+}$ or $\mathrm{Mg}^{2+}$ dramatically decreases the response to ATP. These ionic effects are correlated with in vivo ATP hydrolysis,

binding sites, as represented by decreased $B_{\max }$ values. All these changes are reversible (de-adaptation) after $12 \mathrm{~min}$ in a repellent-free buffer. Electrophysiological analysis showed that both $\beta$ - $\gamma$-methylene ATP $\left(10 \mu \mathrm{moll}^{-1}\right)$ and ATP $\left(500 \mu \mathrm{moll}^{-1}\right)$ elicited sustained, reversible depolarizations while GTP $\left(10 \mu \mathrm{moll}^{-1}\right)$ produced a transient depolarization, suggesting that the chemosensory response pathways for ATP and GTP reception may differ. There may be separate ATP and GTP receptors since ATP and GTP responses do not cross-adapt and 'cold' (unlabeled) GTP is not a good inhibitor of $\left[{ }^{32}\right.$ P]ATP binding. These results suggests that $T$. thermophila possess high-affinity surface receptors for ATP that are downregulated during chemosensory adaptation. These ATP receptors may act as chemorepellent receptors to enable $T$. thermophila to recognize recently lysed cells and avoid a possibly deleterious situation. This is the simplest eukaryotic organism to show an electrophysiological response to external ATP.
\end{abstract} suggesting that divalent ions decrease purinergic sensitivity by activating a $\mathrm{Ca}^{2+}$ - or $\mathrm{Mg}^{2+}$-dependent ecto-ATPase to hydrolyze the ATP signal. In vivo $\left[{ }^{32} \mathrm{P}\right] \mathrm{ATP}$ binding studies and Scatchard analysis suggest that the behavioral adaptation is due to a decrease in the number of surface
Key words: chemorepellent, chemosensory adaptation, desensitization, down-regulation, ecto-ATPase, P2 receptor, Tetrahymena thermophila.

\section{Introduction}

Tetrahymena thermophila respond to micromolar concentrations of depolarizing chemorepellents such as lysozyme, GTP and oxidants (Francis and Hennessey, 1995; Kuruvilla et al., 1997; Kuruvilla and Hennessey, 1998) by showing repeated backward swimming events, or avoidance reactions. Since these cells can be easily visualized under a simple dissection microscope, the avoidance reactions can be used as a quantitative bioassay for these repellents. The ability to purify chemorepellent receptors and measure the electrophysiological responses to repellents (Kuruvilla and Hennessey, 1998) makes Tetrahymena thermophila a very attractive model system for chemosensory transduction studies (Csaba, 1985).

Depolarizing chemorepellents are important for unicellular chemosensory responses because they serve not only as signaling ligands on their own but they can also modify attractant hyperpolarizing responses. As a result, these cells integrate positive and negative chemosensory stimuli in a manner similar to that of neuronal integration of excitatory and inhibitory inputs. Chemorepellent responses are not only relevant for ciliate motility, but also to the axonal guidance systems of developing neurons (He and Tessier-Lavigne, 1997; Kolodkin et al., 1997; Messersmith et al., 1995). It has been shown that the direction of axonal development is determined by both chemoattractant and chemorepellent gradients (Messersmith et al., 1995). A chemorepellent receptor has recently been purified from developing neurons and identified as neuropilin (He and TessierLavigne, 1997; Kolodkin et al., 1997). 
Most sensory cells show chemosensory adaptation and decrease their responsiveness to an external ligand following prolonged exposure to that stimulus. This chemosensory adaptation often involves some type of receptor desensitization. Desensitization can occur via receptor downregulation, covalent modification of the receptor structure or regulation of a component of the second-messenger pathway. Chemosensory adaptation to the repellents GTP and lysozyme in both Paramecium tetraurelia (Kim et al., 1997) and Tetrahymena thermophila (Kuruvilla et al., 1997) involves a reversible decrease in the behavioral response of the cell to the repellent together with a decrease in the number of cell surface receptors. However, it is not yet known how the number of functional surface receptors is regulated in these cells.

Along with the well-established role of nucleoside triphosphates in intracellular metabolism, these compounds have also been found to have external effects in virtually every major organ and/or tissue system studied (Burnstock, 1972, 1996; North and Barnard, 1997). The receptors for nucleoside triphosphates, such as ATP, constitute a large and diverse family and have been referred to as P2-purinergic receptors, purinoceptors (Abbracchio et al., 1993; Harden et al., 1995) or simply P2 receptors (North and Barnard, 1997). This family of P2 receptors is further subdivided on the basis of pharmacological potencies and selectivity of coupling to second-messenger pathways (North and Barnard, 1997). However, definitive classification often requires purification, cloning and expression of the receptor (North and Barnard, 1997; Soto et al., 1997).

Many P2 receptors utilize ligand-gated ion channels and are involved in the physiology of peripheral and central neurons (Edwards et al., 1992; Evans et al., 1992; North and Barnard, 1997; Silinsky and Gerzanich, 1993; Valera et al., 1994), cardiac muscle cells (Danziger et al., 1988; Christie et al., 1992) and smooth muscle cells (Valera et al., 1994). The P2 receptors are further divided into multiple subtypes since channels in different cell types may not have identical ligand selectivities, ion permeabilities and intracellular second-messenger involvement (Brake et al., 1994; North and Barnard, 1997; Soto et al., 1997; Valera et al., 1994). For example, seven subtypes of P2X receptors have been cloned and are known to be ligand-gated channels, while the five mammalian subtypes of P2Y receptor that have been cloned are coupled to G-proteins linked to secondmessenger systems (North and Barnard, 1997; Soto et al., 1997). The interactions of ATP and its analogs with many P2 receptors on neurons and muscle cells have been found to result in a depolarizing current (Bean and Friel, 1990; Dubyak and ElMoatassim, 1993; North and Barnard, 1997; Soto et al., 1997).

While ATP is a potent agonist for many P2 receptors, the non-hydrolyzable analogs $\alpha-\beta$-methylene ATP and $\beta-\gamma$ methylene ATP are often more potent in tissue studies (Abbracchio et al., 1993; Burnstock, 1996; Harden et al., 1995). Although it was initially thought that the potencies of these analogs was due to the ligand selectivity of the receptors involved, it was later found that most of these cells also have a very active ecto-ATPase (Plesner, 1995), which may decrease the amount of intact ligand recognized at the receptor (White,
1988). This could explain the increased potencies of the nonhydrolyzable analogs. Since no universally reliable ectoATPase inhibitors are known (Plesner, 1995), it is difficult to resolve this problem in such tissue studies. However, the cloning and expression of $\mathrm{P} 2$ receptors has demonstrated that ATP is the most potent analog for many P2X-type P2 receptors (North and Barnard, 1997; Soto et al., 1997).

In the present study, we report that both ATP and $\beta-\gamma$ methylene ATP are depolarizing chemorepellents in $T$. thermophila and that the chemosensory transduction of this response may be mediated via functional surface receptors that show specific desensitization during adaptation.

\section{Materials and methods}

Cell cultures

Tetrahymena thermophila $\mathrm{B}$, serotype $\mathrm{H} 3$, was a generous gift from N. E. Williams, University of Iowa. For behavioral studies, cells were grown for $48 \mathrm{~h}$ at $25^{\circ} \mathrm{C}$ in the axenic medium of Dentler (1998) without the addition of antibiotics and without shaking. For all other studies, cells were grown for $72 \mathrm{~h}$ in the same medium and incubated on a rotary shaker at $25^{\circ} \mathrm{C}$ during growth.

\section{Chemicals and solutions}

The general wash solution for the behavioral bioassays contained $10 \mathrm{mmoll}^{-1}$ Trizma base, $0.5 \mathrm{mmoll}^{-1}$ Mops, $1.0 \mathrm{mmoll}^{-1}$ disodium tartarate, $50 \mu \mathrm{moll}^{-1} \mathrm{CaCl}_{2}, \mathrm{pH} 7.0$ at $25^{\circ} \mathrm{C}$. However, disodium tartarate was not added to either the test solutions in the experiments described in Fig. 2 or the in vivo ecto-ATPase assay solutions.

Electrophysiological recordings were carried out at $25^{\circ} \mathrm{C}$ in a buffer containing $1.0 \mathrm{mmoll}^{-1} \mathrm{CaCl}_{2}, 1.0 \mathrm{mmoll}^{-1} \mathrm{Mops}, \mathrm{pH} 7.2$, under conditions previously described (Kuruvilla and Hennessey, 1998) or with the addition of $10 \mathrm{mmoll}^{-1}$ tetraethylammonium chloride (TEA-Cl) (with 2 moll $^{-1} \mathrm{CsCl}$ electrodes) to block $\mathrm{K}^{+}$ conductances (Hennessey and Kung, 1987).

The $\left[{ }^{32} \mathrm{P}\right] \mathrm{ATP}$ in vivo binding assays were performed at $25^{\circ} \mathrm{C}$ in a buffer containing $10 \mathrm{mmoll}^{-1}$ Trizma base, $0.5 \mathrm{mmol}^{-1}$ Mops, $1.0 \mathrm{mmol}^{-1}$ disodium tartarate, $10 \mu \mathrm{moll}^{-1}$ EGTA, pH 7.0. EGTA was added to inhibit ATP hydrolysis by the $\mathrm{Ca}^{2+}$-dependent ecto-ATPase (Smith et al., 1996), while disodium tartarate was added as a precaution, since preliminary evidence showed that tartrate may inhibit ATP hydrolysis by a non-specific acid phosphatase.

For ATP binding studies, $\gamma$-labeled [ $\left.{ }^{32} \mathrm{P}\right]$ ATP Easytides (with a specific activity of $1.1 \times 10^{14} \mathrm{~Bq} \mathrm{mmol}^{-1}$ ) were obtained from Dupont/NEN, Boston, MA, USA. All other compounds were supplied by Sigma Chemical Co., St Louis, MO, USA, unless otherwise noted.

\section{Behavioral assays}

The chemorepellent behavioral assay was the same as previously described for Paramecium tetraurelia (Hennessey et al., 1995) and Tetrahymena thermophila (Kuruvilla et al., 1997). This bioassay measures the initial responses of cells when they are first exposed to a new solution. Briefly, individual cells were 
transferred using a micropipette to a well containing a test solution, and swimming behavior was observed for several seconds under a simple dissection microscope. Cells that showed any significant backward swimming events (avoidance reactions) were scored as positive responders. Ten cells were scored for avoidance $(+$ or - ) for each trial. The mean \pm S.D. was calculated for three trials and expressed as the percentage of cells showing avoidance reactions.

In the adaptation experiments, cells were placed in either $0.5 \mathrm{mmoll}^{-1}$ ATP or $1.0 \mu \mathrm{moll}^{-1} \beta$ - $\gamma$-methylene ATP for varying times. Periodically, cells were transferred to fresh ATP solutions as a precautionary measure in case ATP hydrolysis had occurred. Cells were washed in buffer for $20 \mathrm{~s}$ then transferred back into the original test solution to assay for repellent responses. For de-adaptation, cells were first incubated in either $0.5 \mathrm{mmoll}^{-1}$ ATP or $1.0 \mu \mathrm{moll}^{-1} \beta-\gamma$ methylene ATP for $10 \mathrm{~min}$, quickly washed in buffer by centrifugation, then placed back in fresh buffer. At various times, cells were transferred from the buffer into the test solution and assayed for repellent responses.

\section{In vivo ecto-ATPase assay}

In vivo ecto-ATPase assays were conducted with intact, live cells at $25^{\circ} \mathrm{C}$. A $5 \mathrm{ml}$ sample of cells (usually at a concentration of $490 \times 10^{3}$ cells ml $\mathrm{m}^{-1}$ ) was washed three times in $10 \mathrm{mmol}^{-1}$ Trizma base, $0.5 \mathrm{mmoll}^{-1} \mathrm{Mops}, 50 \mathrm{mmol}^{-1} \mathrm{CaCl}_{2}$, pH 7.0, and resuspended in $12 \mathrm{ml}$ of buffer. For each concentration point, $560 \mu \mathrm{l}$ of cell suspension (usually $275 \times 10^{3}$ cells) was added to the appropriate dilution of the cation being tested to a final volume of $1.26 \mathrm{ml}$ in a $1.5 \mathrm{ml}$ Eppendorf tube. After incubation for $5 \mathrm{~min}$ in a water bath at $25^{\circ} \mathrm{C}$, the chemorepellent was added to give a final concentration of $700 \mu \mathrm{moll}^{-1}$. This mixture was incubated for an additional $5 \mathrm{~min}$ and then subjected to centrifugation in a TOMY HF-120 Capsule Minicentrifuge (Research Products International Corp., Mt Prospect, IL, USA). After centrifugation, $50 \mu \mathrm{l}$ of the supernatant was withdrawn, and liberated phosphate was detected by the method of Lanzetta et al. (1979) and expressed as nmol $P_{i}$ released $\min ^{-1}$. Time course experiments had previously shown that the response was still linear at $5 \mathrm{~min}$ (data not shown). We estimate that approximately $20 \%$ of the available ATP was hydrolyzed after 5 min with $5 \mathrm{mmoll}^{-1} \mathrm{Ca}^{2+}$ present in the in vivo ecto-ATPase assay. All data are expressed as the mean \pm S.D. of at least three separate determinations.

\section{In vivo binding assays}

In vivo ATP binding assays were performed as previously reported for GTP binding in Paramecium tetraurelia (Kim et al., 1997) and Tetrahymena thermophila (Kuruvilla et al., 1997). All binding assays were carried out at $25^{\circ} \mathrm{C}$ in a solution containing $10 \mathrm{mmoll}^{-1}$ Trizma base, $0.5 \mathrm{mmoll}^{-1}$ Mops, $1.0 \mathrm{mmol}^{-1}$ disodium tartrate, $10 \mu \mathrm{moll}^{-1}$ EGTA, $\mathrm{pH} 7.0$. In a typical assay, $0.2 \mathrm{ml}$ of packed cells (at a concentration of approximately $490 \times 10^{3}$ cells $\mathrm{ml}^{-1}$ ) was washed three times by centrifugation and resuspended in $2.0 \mathrm{ml}$ of buffer. For each concentration point, a $120 \mu \mathrm{l}$ sample of cells was mixed with the appropriate dilution of $\left[{ }^{32} \mathrm{P}\right] \mathrm{ATP}$ to a final volume of $200 \mu \mathrm{l}$ in a $1.5 \mathrm{ml}$ Eppendorf tube. This was vortexed gently, and two $20 \mu \mathrm{l}$ samples were withdrawn for liquid scintillation counting in $2.0 \mathrm{ml}$ of Ecoscint (National Diagnostics, Atlanta, GA, USA). The average of these two samples represented the amount of bound + free $\left[{ }^{32} \mathrm{P}\right]$ ATP. The remaining sample was pelleted by centrifugation, and $20 \mu \mathrm{l}$ of the supernatant was removed for liquid scintillation counting. This represented the amount of free $\left[{ }^{32} \mathrm{P}\right] \mathrm{ATP}$. The amount of ligand-bound radioactivity was determined by subtracting the free activity from the total bound + free activity. All data are expressed as the mean \pm S.D. of at least three separate determinations.

In adapted cells, $0.2 \mathrm{ml}$ of packed cells was resuspended in $100 \mathrm{ml}$ of $1.0 \mu \mathrm{moll}^{-1} \beta$ - $\gamma$-methylene ATP for $10 \mathrm{~min}$. Cells were then washed by centrifugation and resuspended to a final volume of $2.0 \mathrm{ml}$, and $120 \mu \mathrm{l}$ samples of cells were assayed for [32P]ATP binding. For de-adaptation, cells were first adapted to $1.0 \mu \mathrm{moll}^{-1} \beta$ - $\gamma$-methylene ATP for $10 \mathrm{~min}$, washed in binding buffer, then resuspended in the same buffer for $12 \mathrm{~min}$. Cells were then removed in volumes of $120 \mu \mathrm{l}$ and assayed for binding. Scatchard analysis (Scatchard, 1949) was performed with the aid of the computer program LIGAND (ElsevierBiosoft; copyright 1986).

\section{Electrophysiology}

The standard one-electrode whole-cell membrane potential recording procedures used were similar to those previously described for Paramecium tetraurelia (Clark et al., 1993; Hennessey et al., 1995) and Tetrahymena thermophila (Kuruvilla and Hennessey, 1998). The recording buffer contained $1.0 \mathrm{mmol}^{-1} \mathrm{CaCl}_{2}, 1.0 \mathrm{mmol} \mathrm{l}^{-1} \mathrm{Mops}$, pH 7.2 (with $500 \mathrm{mmoll}^{-1} \mathrm{KCl}$ electrodes), and with the addition of $10 \mathrm{mmol}^{-1}$ TEA-Cl for the Cs-TEA condition (with $2.0 \mathrm{~mol} \mathrm{l}^{-1}$ $\mathrm{CsCl}$ electrodes). Membrane potentials were recorded under continuous bath perfusion at a rate of $20.0 \mathrm{ml} \mathrm{min}^{-1}$, with a bath volume of approximately $1.0 \mathrm{ml}$. All data are expressed as the mean \pm S.D. of at least three separate determinations.

\section{Results}

ATP and its non-hydrolyzable analog $\beta$ - $\gamma$-methylene ATP are both effective chemorepellents at micromolar concentrations as measured by our behavioral assays (Fig. 1). It has been reported that Tetrahymena thermophila show a baseline avoidance of approximately 10-20\% in buffer alone (Kuruvilla et al., 1997); therefore, avoidance above this margin was considered significant. T. thermophila showed $\mathrm{EC}_{50}$ values $\left(\mathrm{EC}_{50}\right.$ is the concentration of repellent necessary to elicit avoidance reactions in $50 \%$ of the tested cells) of $0.01-0.02 \mu \mathrm{moll}^{-1}$ for $\beta$ - $\gamma$-methylene ATP and $2-3 \mu \mathrm{moll}^{-1}$ for ATP (Fig. 1). Cells showed maximal responses above $0.1 \mu \mathrm{moll}^{-1} \beta$ - $\gamma$-methylene ATP and $0.5 \mathrm{mmoll}^{-1}$ ATP. GTP has previously been shown to be an effective chemorepellent in T. thermophila with an $\mathrm{EC}_{50}$ between 1 and $2 \mu \mathrm{moll}^{-1}$ (Kuruvilla et al., 1997), but the addition of tartarate (an acid phosphatase inhibitor) increased the sensitivity to GTP by over 200-fold such that the EC50 


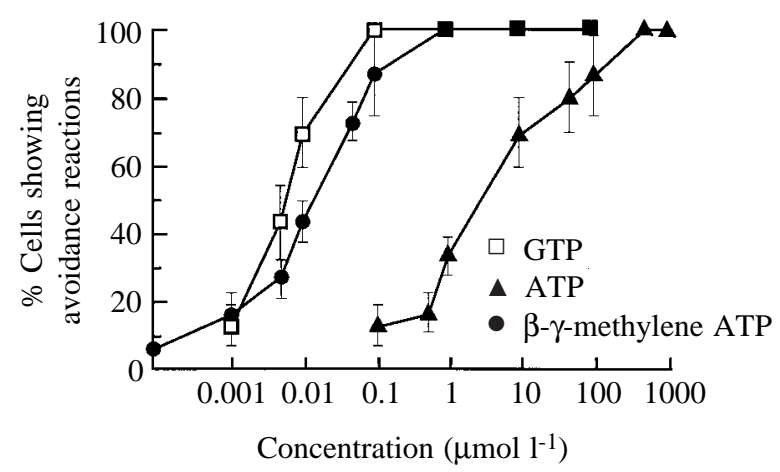

Fig. 1. Tetrahymena thermophila show differential behavioral sensitivities to the purinergic ligands tested. Behavioral bioassays (see Materials and methods) were used to show the concentration dependencies for avoidance reactions to GTP (open squares), ATP (filled triangles) and $\beta$ - $\gamma$-methylene ATP (filled circles). The percentage of cells showing avoidance reactions was determined by observation of single cells after transfer to a test solution. Each trial consisted of ten cells individually scored as + or - responders according to whether a backward swimming event (avoidance reaction) occurred. Each point represents the mean \pm S.D. of three trials.

dropped to between 6 and $7 \mathrm{nmoll}^{-1}$, with a maximal response above $0.1 \mu \mathrm{mol} \mathrm{l}^{-1}$ GTP (Fig. 1).

The behavioral responses of these cells to the chemorepellents used were influenced by increasing concentrations of mono- and divalent cations. Increasing concentrations of $\mathrm{Na}^{+}$in the buffer resulted in similar increased sensitivities of the cells to $1.0 \mathrm{nmoll}^{-1} \mathrm{GTP}, 10 \mu \mathrm{moll}^{-1}$ ATP and $0.5 \mathrm{nmoll}^{-1} \beta$ - $\gamma$-methylene ATP (Fig. 2A). However, increasing concentrations of the divalent cations $\mathrm{Ca}^{2+}$ (Fig. 2B) and $\mathrm{Mg}^{2+}$ (Fig. 2C) resulted in decreased sensitivities to $0.1 \mu \mathrm{moll}^{-1}$ GTP, $0.5 \mathrm{mmoll}^{-1}$ ATP and $1.0 \mu \mathrm{moll}^{-1} \beta-\gamma-$ methylene ATP. The responses to ATP were most sensitive to the divalent ions, while the responses to GTP were less affected by the addition of these ions. The responses to $\beta$ - $\gamma$-methylene ATP were least affected by divalent ion concentrations. These results are consistent with the hypothesis that the existing $\mathrm{Ca}^{2+}$ or $\mathrm{Mg}^{2+}$-dependent ecto-ATPase, which prefers ATP over GTP for hydrolysis (Smith et al., 1996, 1997), may attenuate the responses to ATP by hydrolyzing this ligand in $\mathrm{Ca}^{2+}$ - or $\mathrm{Mg}^{2+}-$ containing solutions. They also suggest that the apparent receptor selectivity inferred from Fig. 1 may actually be due to selective hydrolysis of ATP over GTP.

In vivo ecto-ATPase assays showed that the rate of external ATP hydrolysis was affected by increasing the external concentrations of $\mathrm{Ca}^{2+}$ or $\mathrm{Mg}^{2+}$ but was not affected by $\mathrm{Na}^{+}$ concentration. Increasing concentrations of $\mathrm{Na}^{+}$in the buffer had little or no influence on the rate of ATP hydrolysis (Fig. 3A), while the addition of $\mathrm{Ca}^{2+}$ (Fig. 3B) or $\mathrm{Mg}^{2+}$ (Fig. 3C) resulted in a measurable increase in the rate of hydrolysis. The rate of $\beta$ - $\gamma$-methylene ATP hydrolysis was barely affected at all cation concentrations because of its insensitivity to hydrolysis by the ecto-ATPase (Smith et al., 1996). Because of these divalent ion effects, further
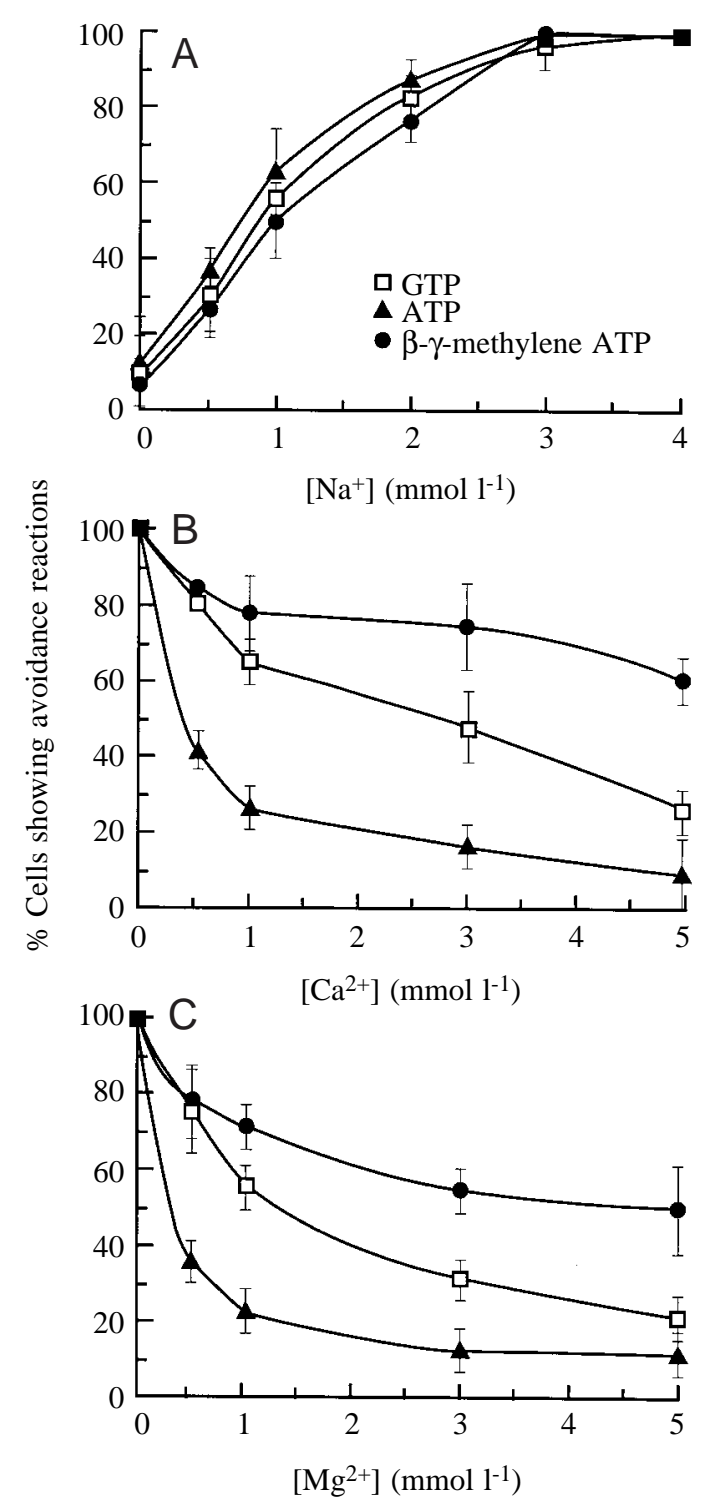

Fig. 2. The behavioral responses to ligands were modified by the addition of divalent cations. (A) Cell sensitivity to $1.0 \mathrm{nmol}^{-1}$ GTP (open squares), $10 \mu \mathrm{moll}^{-1}$ ATP (filled triangles) and $0.5 \mathrm{nmoll}^{-1} \beta$ $\gamma$-methylene ATP (filled circles) was dependent upon the concentration of the monovalent cation $\mathrm{Na}^{+}$in the buffer. Behavioral responses of individual cells were observed for each chemorepellent at increasing concentrations of $\mathrm{Na}^{+}$. (B) Increasing $\mathrm{Ca}^{2+}$ concentrations decreased the behavioral responses to $0.1 \mu \mathrm{moll}^{-1}$ GTP (open squares), $0.5 \mathrm{mmol}^{-1}$ ATP (filled triangles) or $1.0 \mu \mathrm{mol}^{-1} \beta$ - $\gamma$-methylene ATP (filled circles). (C) Increasing concentrations of $\mathrm{Mg}^{2+}$ decreased the behavioral responses to $0.1 \mu \mathrm{moll}^{-1} \mathrm{GTP}$ (open squares), $0.5 \mathrm{mmoll}^{-1}$ ATP (filled triangles) or $1.0 \mu \mathrm{moll}^{-1} \beta$ - $\gamma$-methylene ATP (filled circles). As in all cases, each point represents the mean \pm S.D. of three trials.

experiments employed a buffer with a low $\mathrm{Ca}^{2+}$ concentration $\left(50 \mu \mathrm{moll}^{-1}\right)$ and no $\mathrm{Mg}^{2+}$ to minimize the hydrolysis of ATP.

Behavioral adaptation was observed in response to prolonged exposure to both $0.5 \mathrm{mmoll}^{-1}$ ATP and $1.0 \mu \mathrm{moll}^{-1} \beta-\gamma$ methylene ATP. When cells were placed in either test solution 


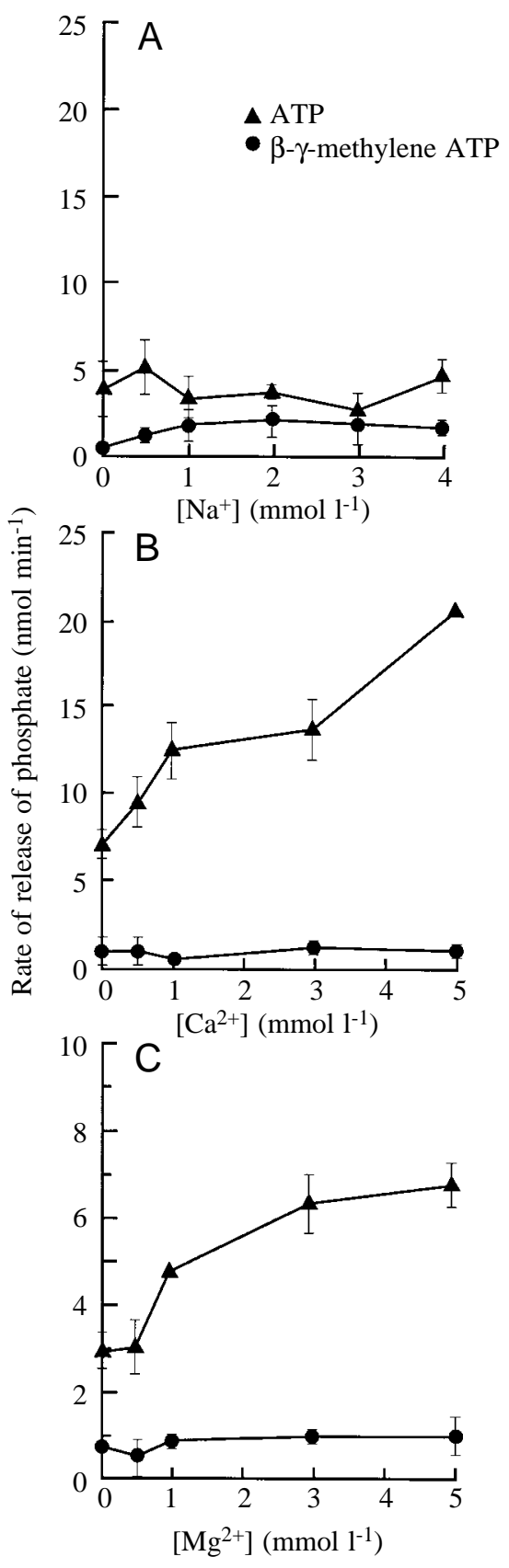

Fig. 3. The extent of ATP hydrolysis was affected by the divalent ions tested but not by $\mathrm{Na}^{+}$. The rate of release of inorganic phosphate was determined by an in vivo ecto-ATPase assay (see Materials and methods) which measured the amount of free phosphate released as a result of ATP hydrolysis. (A) $\mathrm{Na}^{+}$concentration has little or no effect on the hydrolysis of ATP (filled triangles) or $\beta$ - $\gamma$-methylene ATP (filled circles). (B) Addition of increasing concentrations of $\mathrm{Ca}^{2+}$ to the test buffer increased the rate of hydrolysis of ATP (filled triangles), but not that of $\beta$ - $\gamma$-methylene ATP (filled circles), which is not hydrolyzed by the $\mathrm{Ca}^{2+}$-dependent ecto-ATPase. (C) Addition of increasing concentrations of $\mathrm{Mg}^{2+}$ to the test buffer had similar effects to those of $\mathrm{Ca}^{2+}$ in that the rate of ATP (filled triangles) hydrolysis increased and the rate of $\beta-\gamma$-methylene ATP (filled circles) was not affected. In all cases, each point represents the mean \pm S.D. of three experiments. Where no error bars are visible, the deviation from the mean was so small that the symbols are larger than the error. for $10 \mathrm{~min}$ then washed for $20 \mathrm{~s}$ in buffer, they ceased to show any significant avoidance reactions after being retested in that same solution (Fig. 4A). Behavioral adaptation was therefore gradual and time-dependent. It also appears to be specific for each repellent, but cross-adaptation was seen between ATP and $\beta$ - $\gamma$-methylene ATP. Cells that had become behaviorally adapted to $0.1 \mu \mathrm{moll}^{-1}$ GTP after a $10 \mathrm{~min}$ exposure still retained full responsiveness to both $0.5 \mathrm{mmoll}^{-1}$ ATP and $1.0 \mu \mathrm{moll}^{-1} \beta-\gamma$ methylene ATP (Fig. 4B). Cells behaviorally adapted to $0.5 \mathrm{mmoll}^{-1}$ ATP for $10 \mathrm{~min}$ were cross-adapted to $1.0 \mu \mathrm{moll}^{-1}$ $\beta-\gamma$-methylene ATP, yet they still retained full responsiveness to $0.1 \mu \mathrm{moll}^{-1}$ GTP. Similar results were seen with cells adapted to $1.0 \mu$ moll $^{-1} \beta$ - $\gamma$-methylene ATP. It has been reported that $T$. thermophila respond and adapt to the chemorepellent lysozyme, with a maximal response at a concentration of $50 \mu \mathrm{moll}^{-1}$

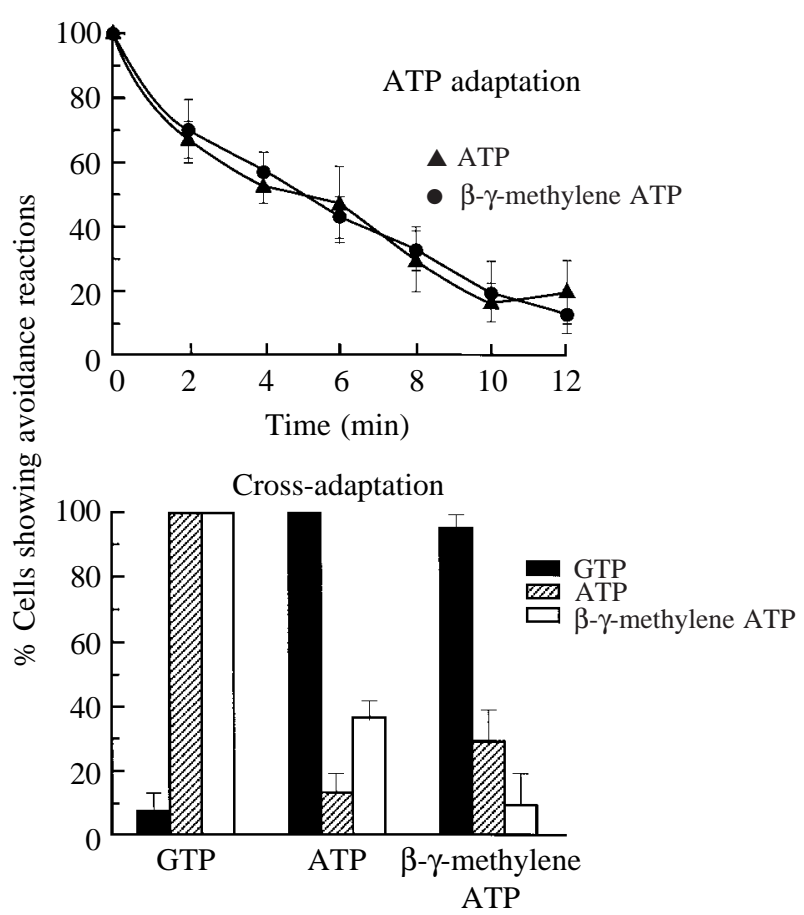

Adaptation solution

Fig. 4. Chemosensory adaptation is seen after prolonged exposure to purinergic ligands. (A) Behavioral adaptation to either ATP or $\beta-\gamma$ methylene ATP was gradual and time-dependent. Individual cells were placed in either $0.5 \mathrm{mmol}^{-1}$ ATP (filled triangles) or $1.0 \mu \mathrm{moll}^{-1} \beta$ - $\gamma$-methylene ATP (filled circles) for varying periods, washed for $20 \mathrm{~s}$ in buffer, then retested in the original repellent solution for avoidance reactions. Full behavioral adaptation occurred after a $10 \mathrm{~min}$ exposure to either repellent. (B) Behavioral adaptation is specific. Cells were allowed to adapt for $10 \mathrm{~min}$ in $0.1 \mu \mathrm{mol} \mathrm{l}^{-1}$ GTP (filled columns), $0.5 \mathrm{mmoll}^{-1}$ ATP (hatched columns) or $1.0 \mu \mathrm{mol}^{-1} \beta$ - $\gamma$-methylene ATP (open columns), washed for $20 \mathrm{~s}$ in buffer, then tested in each of the other repellent solutions. Cells behaviorally adapted to GTP still retained full responsiveness to ATP and to the non-hydrolyzable analog $\beta$ - $\gamma$-methylene ATP. Cells behaviorally adapted to ATP were also adapted to $\beta$ - $\gamma$-methylene ATP and vice-versa. However, cells adapted to either one of these repellents showed full avoidance responses to GTP. In all cases, each point represents the mean \pm S.D. of three experiments. 


\section{M. Y. KIM AND OTHERS}

(Kuruvilla et al., 1997). Adaptation to either ATP or $\beta-\gamma$ methylene ATP did not affect the behavioral response to lysozyme and vice-versa (data not shown).

Chemosensory adaptation to both ATP and $\beta$ - $\gamma$-methylene ATP is completely reversible in our behavioral assay (Fig. 5). Cells that were behaviorally adapted after a $10 \mathrm{~min}$ exposure to either $0.5 \mathrm{mmoll}^{-1}$ ATP or $1.0 \mu \mathrm{moll}^{-1} \beta$ - $\gamma$-methylene ATP could regain full sensitivity to these repellents following a $12 \mathrm{~min}$ incubation in repellent-free wash buffer. As with adaptation, behavioral de-adaptation is gradual and time-dependent.

In vivo binding studies of $T$. thermophila show that $\left[{ }^{32} \mathrm{P}\right] \mathrm{ATP}$ binding is saturable (Fig. 6A), and Scatchard analysis suggests that binding in this concentration range is due to a single class of receptor (Fig. 6B). Binding is similar in cells that have not been adapted to $0.5 \mathrm{mmol}^{-1}$ ATP and cells that have undergone adaptation to ATP followed by de-adaptation in the binding buffer. Binding of ATP to adapted cells was essentially zero, and a dissociation constant $\left(K_{\mathrm{D}}\right)$ could not be determined. Saturable ATP binding to both non-adapted and de-adapted cells showed an apparent $K_{\mathrm{D}}$ of $13 \mathrm{nmoll}^{-1}$ on the basis of Scatchard analysis. Taking into account the number of cells in these assays and the $B_{\max }$ values of $1.09 \mathrm{pmoll}^{-1}$ for nonadapted cells and $1.0 \mathrm{pmoll}^{-1}$ for de-adapted cells, there are approximately $5.24 \times 10^{6}$ receptors per cell on non-adapted cells and $4.81 \times 10^{6}$ ATP receptors per cell on de-adapted cells.

Further binding studies showed that external [ $\left.{ }^{32} \mathrm{P}\right] \mathrm{ATP}$ binding can be inhibited by an excess of unlabeled ATP but that unlabeled GTP was not as effective. A 50-fold excess of unlabeled ATP inhibited [ ${ }^{32} \mathrm{P}$ ]ATP binding by up to $90 \pm 7 \%$ $(N=3)$ compared with the control, and the same excess of $\beta-\gamma$ -

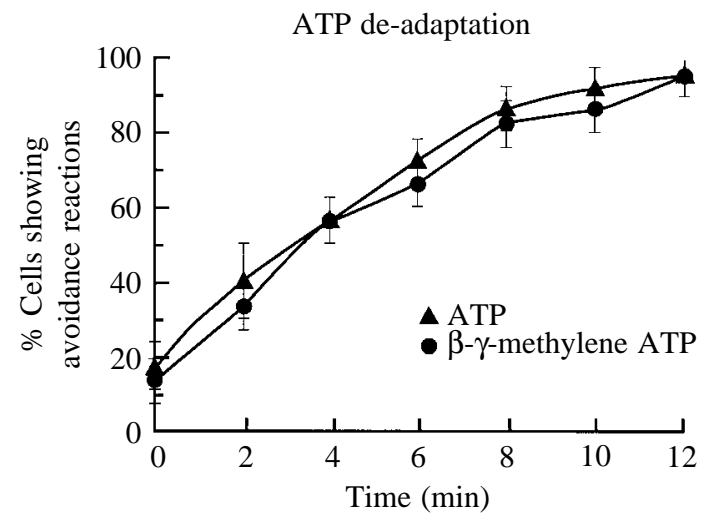

Fig. 5. Behavioral adaptation to either ATP or $\beta$ - $\gamma$-methylene ATP was fully reversible during a process referred to as de-adaptation. Cells preincubated in either $0.5 \mathrm{mmoll}^{-1}$ ATP or $1.0 \mu \mathrm{moll}^{-1} \beta-\gamma$ methylene ATP for $10 \mathrm{~min}$ were transferred to buffer for varying periods then retested in the original test solution. Cells that had completely lost their responsiveness to ATP (see Fig. 2A) showed a time-dependent return to full sensitivity to $0.5 \mathrm{mmoll}^{-1}$ ATP (filled triangles) after $12 \mathrm{~min}$ in a repellent-free solution. Similarly, cells behaviorally adapted to $1.0 \mu \mathrm{moll}^{-1} \beta$ - $\gamma$-methylene ATP (filled circles) for $10 \mathrm{~min}$ regained their sensitivity to the repellent after $12 \mathrm{~min}$ in the control solution. Each point represents the mean \pm S.D. of three experiments.
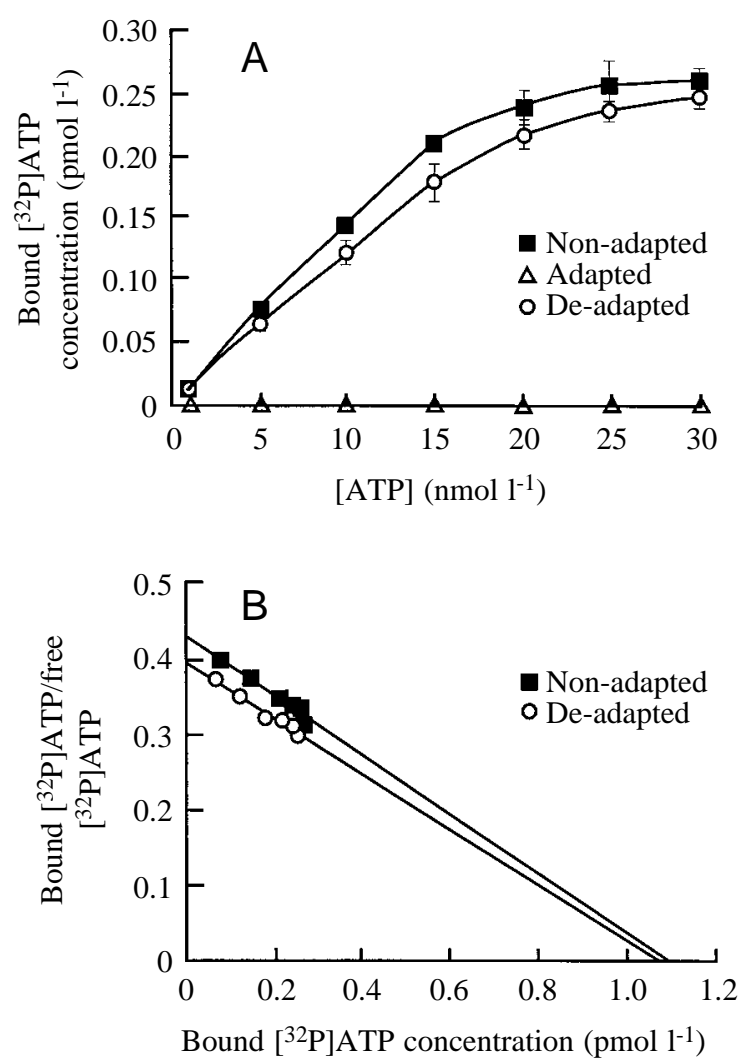

Fig. 6. In vivo $\left[{ }^{32} \mathrm{P}\right] \mathrm{ATP}$ binding to intact cells showed saturable, highaffinity binding to surface receptors in both control and de-adapted cells but this binding was virtually lost in adapted cells. (A) The amount of $\left[{ }^{32} \mathrm{P}\right] \mathrm{ATP}$ bound to cells increased in a concentrationdependent manner in both control (filled squares) and de-adapted (open circles) cells, but adapted cells (open triangles) showed no measurable binding at any concentration tested. Each point represents the mean \pm S.D. of three experiments. (B) Scatchard analysis showed that the apparent $K_{\mathrm{D}}$ of control cells (filled squares) and de-adapted cells (open circles) were identical while the $B_{\max }$ values (a measure of the number of binding sites) were comparable. Values for adapted cells could not be plotted because the bound/free ratios were all zero.

methylene ATP also inhibited binding by up to $85 \pm 1 \%(N=3)$. A 50-fold excess of unlabeled GTP inhibited $\left[{ }^{32} \mathrm{P}\right]$ ATP binding by only $35 \pm 1 \% \quad(N=3)$. Since there may be differential hydrolysis of various nucleoside triphosphates in vivo due to the ecto-ATPase and other phosphatases (Smith et al., 1996, 1997), further competition studies using the purified receptor are needed to establish which compounds are competitive inhibitors of $\left[{ }^{32} \mathrm{P}\right] \mathrm{ATP}$ binding to this receptor.

Whole-cell electrophysiological recordings of $T$. thermophila show a sustained depolarization in response to $0.5 \mathrm{mmol} \mathrm{l}^{-1}$ ATP (Fig. 7A) or $10 \mu \mathrm{moll}^{-1} \beta$ - $\gamma$-methylene ATP (Fig. 7B). The initial resting membrane potential for cells exposed to $10 \mu \mathrm{moll}^{-1} \beta$ - $\gamma$-methylene ATP (Fig. 7B) was $-35.2 \pm 4.1 \mathrm{mV}$, with a change in membrane potential of $14.5 \pm 0.9 \mathrm{mV} \quad(N=7) \quad$ during the repellent-induced depolarization. Under the same recording conditions, $0.5 \mathrm{mmoll}^{-1}$ ATP did not elicit reliable cell depolarizations 
Fig. 7. Sustained, reversible depolarizations were seen in response to either ATP or $\beta$ - $\gamma$-methylene ATP $(\beta-\gamma-\mathrm{m}-\mathrm{ATP})$. (A) Membrane potential recordings from three different cells showed ATP-induced depolarizations in response to $0.5 \mathrm{mmoll}^{-1}$ ATP. These cells were recorded under Cs-TEA conditions in a buffer containing $1.0 \mathrm{mmoll}^{-1} \quad \mathrm{CaCl}_{2}$, $1.0 \mathrm{mmoll}^{-1}$ Mops, $10 \mathrm{mmol}^{-1}$ TEA-Cl, pH 7.2, with $2.0 \mathrm{moll}^{-1} \mathrm{CsCl}$ electrodes. In each trace, ATP was added (at the first arrow) and removed by washing with the buffered solution alone (second arrow). (B) Three other cells showed depolarizations in response to $10 \mu \mathrm{moll}^{-1} \beta$ - $\gamma$-methylene ATP in a buffer containing $1.0 \mathrm{mmoll}^{-1} \mathrm{CaCl}_{2}, 1.0 \mathrm{mmoll}^{-1}$ Mops, $\mathrm{pH} 7.2$, with a $500 \mathrm{mmol}^{-1} \mathrm{KCl}$ electrode. In each trace, $\beta$ - $\gamma$-methylene ATP was added at the beginning of the recording.
A

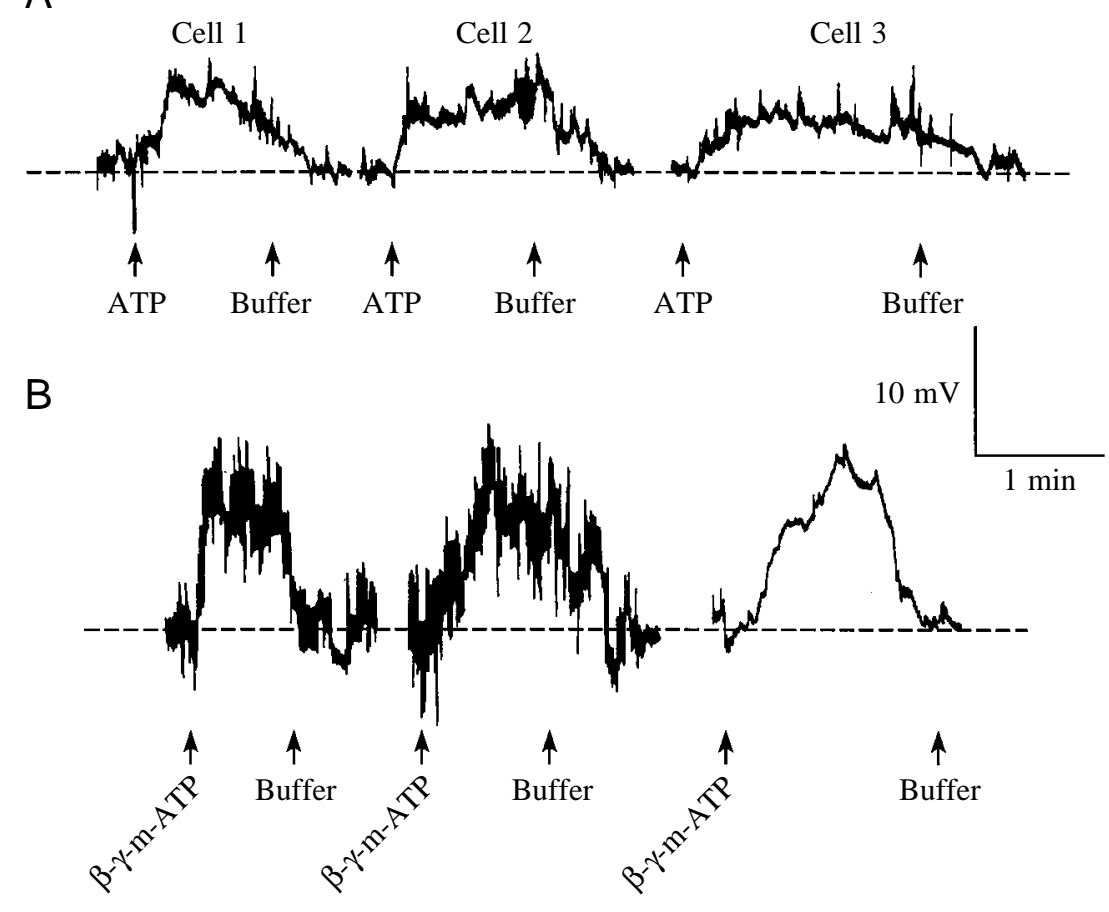

(data not shown), but ATP-induced depolarizations were seen when the $\mathrm{K}^{+}$conductances were blocked with Cs-TEA (Fig. 7A). These cells had a mean resting membrane potential of $-24.5 \pm 3.5 \mathrm{mV}$ and showed a change in potential of $4.8 \pm 0.5 \mathrm{mV}(N=7)$ when exposed to ATP. Unlike the sustained depolarization seen in response to ATP and $\beta$ - $\gamma$-methylene ATP (Fig. 7), $10 \mu \mathrm{moll}^{-1}$ GTP produced a transient depolarization (Fig. 8). The mean resting membrane potential was $-46.3 \pm 5.7 \mathrm{mV}$, and $10 \mu \mathrm{moll}^{-1} \mathrm{GTP}$ caused a change in potential of $17.2 \pm 5.5 \mathrm{mV}(N=9)$.

\section{Discussion}

Our hypothesis is that, as reported for GTP (Kuruvilla et al., 1997), the sensory transduction pathway for ATP-induced avoidance behavior in Tetrahymena thermophila involves activation of high-affinity, discrete, independent surface receptors, causing membrane depolarization and consequent avoidance behavior.

Our behavioral studies demonstrated that both ATP and the non-hydrolyzable analog $\beta$ - $\gamma$-methylene ATP elicit repeated backward swimming events in $T$. thermophila at micromolar concentrations, but that $\beta$ - $\gamma$-methylene ATP is far more effective (Fig. 1). Maximal avoidance reactions occurred in $0.1 \mu \mathrm{moll}^{-1}$ GTP, $0.5 \mathrm{mmoll}^{-1}$ ATP or $0.1 \mu \mathrm{moll}^{-1} \beta-\gamma$ methylene ATP under our test conditions. The results we obtained for GTP differ significantly from a previous report (Kuruvilla et al., 1997) by a concentration factor of more than 200 -fold because of the extreme sensitivity of our assay conditions. A low $\mathrm{Ca}^{2+}$ concentration was used in our buffer to inhibit nucleotide hydrolysis by a soluble, $\mathrm{Ca}^{2+}$-dependent ectoATPase (Smith et al., 1996, 1997). We could not use zero $\mathrm{Ca}^{2+}$ (and EGTA) in the behavioral experiments because a $\mathrm{Ca}^{2+}$ influx is required for ciliary reversal and avoidance reactions. In addition, preliminary data suggest that tartarate may further inhibit nucleoside triphosphate hydrolysis by a non-specific acid phosphatase (Banno et al., 1982). Addition of tartarate (either as the $\mathrm{Na}^{+}$salt or in the free acid form) reliably increased the sensitivity of these cells to external ATP.

While some of the hydrolysis of the ATP signal could be occurring in the bulk solution, the more relevant hydrolysis may be localized on the surface of the cells. Since the behavioral assays involve single cells in a volume of approximately $0.5 \mathrm{ml}$ for only a few seconds, there is little significant bulk hydrolysis

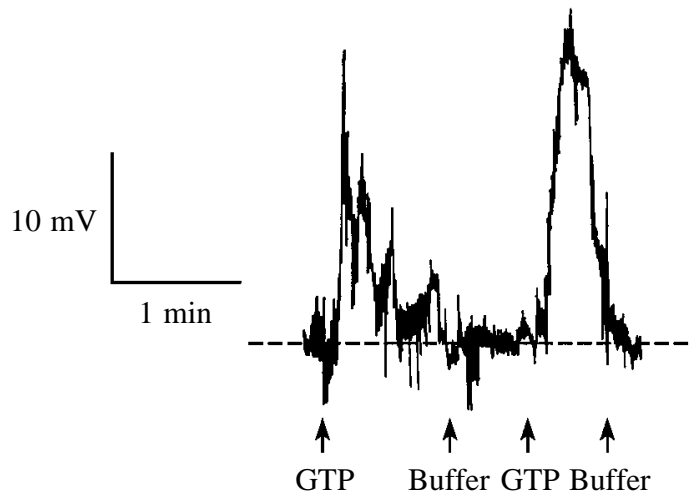

Fig. 8. The GTP-induced depolarization of Tetrahymena thermophila differed from the ATP responses. The response to $10 \mu \mathrm{moll}^{-1}$ GTP was a large, transient depolarization. This cell was bathed in the same recording solution as that used in Fig. 7B and exposed to $10 \mu \mathrm{moll}^{-1}$ GTP, washed with the buffer solution and then reexposed to the GTP solution again to show the variability in the type of responses recorded. 


\section{M. Y. KIM AND OTHERS}

of the ATP in solution. We propose that the ATP receptors, like the GTP receptors in Paramecium tetraurelia (Clark et al., 1993), are on the body membrane while the ecto-ATPases are distributed on both ciliary and body membranes (Smith et al., 1996, 1997). Since the cells are covered with constantly beating cilia (with high ecto-ATPase activity), the actual intact ATP concentration at the body receptor may be lower than the bulk solution ATP concentration. This could explain why ATP is more effective at low concentrations of $\mathrm{Ca}^{2+}$ (Fig. 2A), since the in vivo ecto-ATPase activity is $\mathrm{Ca}^{2+}$-dependent (Fig. 3B). This is further supported by the fact that the non-hydrolyzable analog of ATP is more effective than ATP itself (Fig. 1).

The monovalent cation $\mathrm{Na}^{+}$influenced the behavioral responses observed but had no effect on the rate of ATP hydrolysis. Increasing concentrations of $\mathrm{Na}^{+}$in the testing buffer increased cell sensitivity to GTP, ATP and $\beta$ - $\gamma$-methylene ATP (Fig. 2A). This $\mathrm{Na}^{+}$-dependence is consistent with the idea of a $\mathrm{Ca}^{2+}$-dependent $\mathrm{Na}^{+}$channel such as that found in the related ciliate Paramecium tetraurelia (Saimi and Kung, 1980), in which $\mathrm{Na}^{+}$also increases the responses to GTP (Clark et al., 1997). No such channel has yet been described in $T$. thermophila however. This $\mathrm{Na}^{+}$-dependence was not related to ATP hydrolysis since there was little or no $\mathrm{Na}^{+}$-dependence for phosphate release as measured by our in vivo ecto-ATPase assay (Fig. 3A).

An increase in the concentration of the divalent cations $\mathrm{Ca}^{2+}$ and $\mathrm{Mg}^{2+}$ in the test buffer resulted in a decrease in cell sensitivity to GTP, ATP and (to a lesser extent) $\beta$ - $\gamma$-methylene ATP (Fig. 2B,C). These behavioral data can be correlated with the external hydrolysis of ATP. An increase in $\mathrm{Ca}^{2+}$ or $\mathrm{Mg}^{2+}$ concentration resulted in an increase in the rate of ATP hydrolysis (Fig. 3B,C). Since ATPase activity increased with the concurrent increases in $\mathrm{Ca}^{2+}$ or $\mathrm{Mg}^{2+}$ concentrations, there was a decrease in the amount of ATP present to modify the behavior of the cells (Fig. 2B,C). However, the ATP analog $\beta$ - $\gamma$-methylene ATP is non-hydrolyzable and, therefore, was resistant to the increased divalent cation concentrations. These results are in contrast to those in Paramecium tetraurelia, where the responses to GTP are increased with increasing concentrations of $\mathrm{Mg}^{2+}$ (Clark et al., 1997). One possible explanation for this may be that the responses of Paramecium tetraurelia to GTP are increased in the presence of $\mathrm{Mg}^{2+}$ because of the presence of a $\mathrm{Ca}^{2+}$-dependent $\mathrm{Mg}^{2+}$ conductance (Clark et al., 1997), although there is currently no evidence for the existence of such a conductance in $T$. thermophila. In addition, we cannot explain the divalent ion sensitivities of the behavioral responses to $\beta$ - $\gamma$-methylene ATP (Fig. 2B,C). This is apparently unrelated to extensive hydrolysis (see Fig. 3B,C), so it may represent a different ionic effect (such as a change in conformation of phosphate groups).

It has been reported previously that the soluble, $\mathrm{Ca}^{2+}$ dependent ecto-ATPase from $T$. thermophila prefers hydrolysis of ATP over GTP by a factor of almost 4:1 (Smith et al., 1996, 1997). This could explain why the cells responded (behaviorally) to lower concentrations of GTP than of ATP (Fig. 1). However, the cells were as sensitive to the same concentrations of the non-hydrolyzable analog of ATP as they were to GTP under the conditions used in Fig. 1. While this suggested that both these ligands might bind to the same receptor, cross-adaptation experiments (Fig. 4) and GTP competition experiments (see Results) suggested that there might actually be separate receptors for ATP and GTP.

Chemosensory adaptation is the process by which sensory cells decrease their responsiveness to an external ligand during prolonged exposure to that stimulus. $T$. thermophila have already been reported to adapt to external lysozyme and GTP (Kuruvilla et al., 1997). The ability to adapt to an external ligand has also been demonstrated in other chemotactic cells such as leukocytes and Dictyostelium discoideum (Devreotes and Zigmond, 1988), as well as in Paramecium tetraurelia (Kim et al., 1997). Adaptation to ionic stimuli has also been described in Paramecium tetraurelia (Dryl, 1952; Oka et al., 1986; Preston and Hammond, 1998), but this does not involve a specific chemoreceptor and some experiments use stimuli other than the adapting stimulus for assaying 'adaptation' (Preston and Hammond, 1998).

We describe here the adaptation of $T$. thermophila to external ATP (Fig. 4A) in a gradual and time-dependent manner. Cells exposed to $0.5 \mathrm{mmol}^{-1}$ ATP for $10 \mathrm{~min}$ showed no avoidance reactions when retested in $0.5 \mathrm{mmol}^{-1}$ ATP after a $20 \mathrm{~s}$ wash in repellent-free buffer. Similar results were seen with cells exposed to $1.0 \mu \mathrm{moll}^{-1} \beta$ - $\gamma$-methylene ATP for $10 \mathrm{~min}$. This adaptation was not due to ADP (or other metabolites) generated by hydrolysis of ATP because cells showed normal responses to ATP after $10 \mathrm{~min}$ in $0.5 \mathrm{mmoll}^{-1}$ ADP. Similarly, previous adaptation to ADP did not affect ${ }^{32} \mathrm{P}[\mathrm{ATP}]$ binding (data not shown). This relatively long time scale $(10 \mathrm{~min})$ will simplify future experiments concerning the biochemical mechanisms involved in adaptation to ATP.

Adaptation appears to be specific since cells adapted to one chemorepellent are still behaviorally responsive to a different repellent (Fig. 4B). Cells adapted to $0.1 \mu \mathrm{moll}^{-1} \mathrm{GTP}$ for $10 \mathrm{~min}$ show maximal avoidance reactions in either $0.5 \mathrm{mmoll}^{-1}$ ATP or $1.0 \mu \mathrm{moll}^{-1} \quad \beta$ - $\gamma$-methylene ATP. Similarly, cells adapted to $0.5 \mathrm{mmol}^{-1}$ ATP or $1.0 \mu \mathrm{mol}^{-1}$ $\beta$ - $\gamma$-methylene ATP for $10 \mathrm{~min}$ still retain their behavioral responses to $0.1 \mu \mathrm{moll} \mathrm{l}^{-1} \mathrm{GTP}$. However, cells adapted to ATP are also adapted to $\beta$ - $\gamma$-methylene ATP, and vice-versa. Kuruvilla et al. (1997) have reported that T. thermophila still retained full sensitivity to $50 \mu \mathrm{moll}^{-1}$ lysozyme after adaptation to $20 \mu \mathrm{moll}^{-1}$ GTP. We have also found that adaptation to either ATP or $\beta$ - $\gamma$-methylene ATP had no effect on the responsiveness of the cells to lysozyme (data not shown). Similarly, cells behaviorally adapted to $50 \mu \mathrm{mol}^{-1}$ lysozyme for $10 \mathrm{~min}$ still showed maximal avoidance reactions to both $0.5 \mathrm{mmol}^{-1}$ ATP and $1.0 \mu \mathrm{mol}^{-1} \beta$ - $\gamma$ methylene ATP.

Cells fully adapted to an external ligand can regain their sensitivity to that stimulus when exposed to a repellent-free solution over time. De-adaptation to either ATP or $\beta$ - $\gamma$-methylene ATP is also gradual and time-dependent, as with adaptation (Fig. 5). This demonstrates that adaptation is fully reversible and cannot, therefore, be attributed simply to adverse effects of the chemorepellents. Since the time course for de-adaptation requires 
up to $12 \mathrm{~min}$, the $20 \mathrm{~s}$ wash used during the behavioral studies should not cause any significant de-adaptation before retesting.

In vivo binding studies for $\left[{ }^{32} \mathrm{P}\right] \mathrm{ATP}$ demonstrate saturable, high-affinity cell surface ATP binding. To reduce ATP hydrolysis, the binding buffers contained both tartarate, which inhibits hydrolysis by the non-specific acid phosphatase (Banno et al., 1982), and EGTA, which inhibits the $\mathrm{Ca}^{2+}$-dependent ecto-ATPase (Smith et al., 1996). The results presented in Fig. 6 suggest a single class of surface ATP-binding receptors with an apparent $K_{\mathrm{D}}$ for ATP of $13 \mathrm{nmoll}^{-1}$ and an estimated $5.24 \times 10^{6}$ surface receptors per cell. This was due to true external $\left.{ }^{32} \mathrm{P}\right]$ ATP binding and not to uptake of radioactivity because, when cell pellets were quickly washed (for less than $20 \mathrm{~s}$ ) with $1.0 \mathrm{ml}$ of cold buffer solution (after exposure to $25 \mathrm{nmoll}^{-1}$ $\left[{ }^{32} \mathrm{P}\right]$ ATP for the normal time of the assay), only $2.7 \pm 2.0 \%$ of the radioactivity remained associated with the cells. It is unlikely that the $\left.{ }^{32} \mathrm{P}\right] \mathrm{ATP}$ binding was due to the ecto-ATPase because this enzyme has such a high $K_{\mathrm{m}}\left(0.24 \mathrm{mmoll}^{-1}\right)$ for ATP in $T$. thermophila (Smith et al., 1996, 1997).

Behavioral adaptation appears to be controlled via the downregulation or modification of functional surface receptors. As a result of ATP adaptation, bound external [ $\left.{ }^{32} \mathrm{P}\right] \mathrm{ATP}$ could no longer be measured in our binding assays (Fig. 6A). This adaptation is reversible since de-adapted cells show a return of [32 P]ATP binding similar to that of control cells. Competition studies show that ATP binding is specific and reversible. A 50fold excess of non-radioactive ATP inhibited $\left[{ }^{32} \mathrm{P}\right] \mathrm{ATP}$ binding by up to $90 \%$, while a similar level of $\beta$ - $\gamma$-methylene ATP inhibited [ $\left.{ }^{32} \mathrm{P}\right] \mathrm{ATP}$ binding by $85 \%$.

Electrophysiological studies show that the responses of $T$. thermophila to ATP and $\beta$ - $\gamma$-methylene are a result of a sustained depolarization (Fig. 7). The depolarization induced by $10 \mu \mathrm{mol}^{-1} \beta$ - $\gamma$-methylene ATP averaged approximately $15 \mathrm{mV}$ under buffer conditions of $1.0 \mathrm{mmol}^{-1}$ external $\mathrm{Ca}^{2+}$ (Fig. 7B). However, it was difficult to elicit cell membrane depolarizations in response to $0.5 \mathrm{mmoll}^{-1}$ ATP under these same buffer conditions. Under Cs-TEA conditions (with the addition of $10 \mathrm{mmol}^{-1}$ TEA-Cl to the buffer), a small ATPinduced depolarization of approximately $5 \mathrm{mV}$ was uncovered (Fig. 7A). The reasons that the ATP-induced depolarizations only occur reliably when the $\mathrm{K}^{+}$conductances are blocked by Cs-TEA may be related either to some uncharacterized, repolarizing conductances or simply to the fact that these depolarizations are small and that some aspect of the Cs-TEA procedure helps to amplify them. These sustained ATPinduced depolarizations differ from the lysozyme-induced depolarizations described previously (Kuruvilla and Hennessey, 1998). The lysozyme-induced depolarizations are transient and large, averaging approximately $50 \mathrm{mV}$. Unlike the sustained depolarization caused by ATP, the GTP-induced depolarization was transient (Fig. 8). Both these responses differed from the GTP-induced depolarizations seen in Paramecium tetraurelia (Clark et al., 1993, 1997; Kim et al., 1997). Although both Tetrahymena thermophila and Paramecium tetraurelia show a transient GTP-induced depolarization, the GTP-induced response in Tetrahymena thermophila was a single depolarization of approximately $17 \mathrm{mV}$ (with the membrane potential of the cell returning to the resting level) (Fig. 8), whereas in Paramecium tetraurelia, cells show repetitive depolarizations (Clark et al., 1993).

Behaviorally, the responses to ATP and GTP in Tetrahymena thermophila are simple avoidance reactions, while the response to GTP in Paramecium tetraurelia involves repetitive bouts of longer backward swimming. In Paramecium tetraurelia, this is correlated with the indicative oscillating, long plateau depolarizations seen in response to GTP (Clark et al., 1993). Interestingly, a new behavioral mutant of Paramecium tetraurelia has been described (called ginA) that lacks the oscillating GTP-induced depolarizations and shows only a sustained depolarization in response to GTP (Mimikakis et al., 1998). The behavioral response of the ginA mutant is, like that of Tetrahymena thermophila, repetitive avoidance reactions without periods of backward swimming (T. M. Hennessey, personal observations).

The results presented here suggest that Tetrahymena thermophila respond behaviorally and electrophysiologically to ATP or $\beta$ - $\gamma$-methylene ATP and that this response is mediated via functional membrane receptors. Our assay conditions, which minimize the hydrolysis of nucleoside phosphates, reduce the possibility that the results are due to ADP, AMP or adenosine, and incubation in $0.5 \mathrm{mmol}^{-1}$ ADP fails to trigger either avoidance reactions or adaptation. These results, coupled with the fact that the non-metabolizable form of ATP ( $\beta$ - $\gamma$-methylene ATP) has effects similar to those of ATP, lead us to believe that the ATP-induced responses are mediated via ATP-binding receptors. We have also seen similar behavioral, electrophysiological and binding results in Paramecium tetraurelia, which suggests that these cells may possess similar receptors (M. Kim and T. M. Hennessey, unpublished observations).

An ATP-binding receptor in Tetrahymena thermophila and the related ciliate Paramecium tetraurelia could be an evolutionary precursor for similar P2 receptors described previously (North and Barnard, 1997; Soto et al., 1997). Understanding the mechanisms involved in the chemosensory transduction processes of this simple model system could provide insights into the physiological and pathological importance of ATP and the transduction of its response via the ATP-binding receptors in higher eukaryotes. Additional studies will be necessary for further classification of these receptors in Tetrahymena thermophila and Paramecium tetraurelia and to determine their similarities to the ATP-binding receptors of other organisms.

This work was supported by NSF grant MCB9410756 to T.M.H.

\section{References}

Abbracchio, M. P., Cattabeni, F., Fredholm, B. B. and Williams, M. (1993). Purinoceptor nomenclature: A status report. Drug Dev. Res. 28, 207-213.

Banno, Y., Yano, K. and Nozawa, Y. (1982). Biochemical characterization of secreted proteases during growth in 
Tetrahymena thermophila pyriformis WH-14: Comparison of extracellular and intracellular proteases. J. Protozool. 29, 91-98.

Bean, B. P. and Friel, D. D. (1990). ATP-activated channels in excitable cells. In Ion Channels (ed. T. Narahashi), pp. 169-203. New York: Plenum Press.

Brake, A. J., Wagenbach, M. J. and Julius, D. (1994). New structural motif for ligand-gated ion channels defined by an ionotropic ATP receptor. Nature 371, 519-523.

Burnstock, G. (1972). Puringeric nerves. Pharmac. Rev. 24, 509-581.

Burnstock, G. (1996). Development and perspectives of the purinoceptor concept. J. Autonom. Pharmac. 16, 295-302.

Christie, A., Sharma, V. K. and Sheu, S. S. (1992). Mechanism of extracellular ATP-induced increase of cytosolic $\mathrm{Ca}^{2+}$ concentration in isolated rat ventricular myocytes. J. Physiol., Lond. 445, 369-388.

Clark, K., Hennessey, T. M. and Nelson, D. L. (1993). External GTP alters the motility and elicits an oscillating membrane depolarization in Paramecium tetraurelia. Proc. Natl. Acad. Sci. USA 90, 3782-3786.

Clark, K. D., Hennessey, T. M., Nelson, D. L. and Preston, R. R. (1997). Extracellular GTP causes membrane potential oscillations through the parallel activation of $\mathrm{Mg}^{2+}$ and $\mathrm{Na}^{+}$currents in Paramecium tetraurelia. J. Membr. Biol. 157, 159-167.

Csaba, G. (1985). The unicellular Tetrahymena thermophila as a model cell for receptor research. Int. Rev. Cytol. 95, 327-377.

Danziger, R. S., Raffaeli, S., Moreno-Sanchez, R., Sakai, M., Capogrossi, M. C., Spurgeon, H. A. and Lakatta, E. G. (1988). Extracellular ATP has a potent effect to enhance cytosolic calcium and contractility in single ventricular myocytes. Cell Calcium 9, 193-199.

Dentler, W. L. (1988). Fractionation of Tetrahymena thermophila ciliary membranes with Triton X-114 and the identification of a ciliary membrane ATPase. J. Cell Biol. 107, 2679-2688.

Devreotes, P. and Zigmond, S. (1988). Chemotaxis in eukaryotic cells: a focus on leukocytes and Dictyostelium. Annu. Rev. Cell Biol. 4, 649-686.

Dryl, S. (1952). The dependence of chemotropism in Paramecium caudatum on the chemical changes in the medium. Acta Biol. Exp. 16, 23-53.

Dubyak, G. R. and El-Moatassim, C. (1993). Signal transduction via $\mathrm{P}_{2}$-purinergic receptor for extracellular ATP and other nucleotides. Am. J. Physiol. 265, C577-C606.

Edwards, F. A., Gibb, A. J. and Colquhoun, D. (1992). ATP receptor-mediated synaptic currents in the central nervous system. Nature 359, 144-147.

Evans, R. J., Derkach, V. and Surprenant, A. (1992). ATP mediates fast synaptic transmission in mammalian neurons. Nature 357, 503-505.

Francis, J. T. and Hennessey, T. M. (1995). Chemorepellents in Paramecium tetraurelia and Tetrahymena thermophila. J. Euk. Microbiol. 42, 78-83.

Harden, T. K., Boyer, J. L. and Nicholas, R. A. (1995). P2purinergic receptors: Subtype-associated signalling responses and structure. Annu. Rev. Pharmac. Toxicol. 35, 541-579.

He, Z. and Tessier-Lavigne, M. (1997). Neuropilin is a receptor for the axonal chemorepellent Semaphorin III. Cell 90, 739-751.

Hennessey, T. M., Kim, M. Y. and Satir, B. H. (1995). Lysozyme acts as a chemorepellent and secretagogue in Paramecium tetraurelia by activating a novel receptor-operated $\mathrm{Ca}^{2+}$ conductance. J. Membr. Biol. 148, 13-25.

Hennessey, T. M. and Kung, C. (1987). A single calcium-dependent potassium current is increased by a single-gene mutation in Paramecium tetraurelia. J. Membr. Biol. 98, 145-155.

Kim, M. Y., Kuruvilla, H. G. and Hennessey, T. M. (1997). Chemosensory adaptation in Paramecium tetraurelia involves changes in both repellent binding and the consequent receptor potentials. Comp. Biochem. Physiol. 118, 589-597.

Kolodkin, A. L., Levengood, D. V., Rowe, E. G., Tai, Y.-T., Giger, R. J. and Ginty, D. D. (1997). Neuropilin is a Semphorin III receptor. Cell 90, 753-762.

Kuruvilla, H. G. and Hennessey, T. M. (1998). Purification and characterization of a novel lysozyme chemoreceptor from Tetrahymena thermophila. J. Membr. Biol. 162, 51-57.

Kuruvilla, H. G., Kim, M. Y. and Hennessey, T. M. (1997). Chemosensory adaptation to lysozyme and GTP involves independently regulated receptors in Tetrahymena thermophila. J. Euk. Microbiol. 44, 263-268.

Lanzetta, P. A., Alvarez, L. J., Reinach, P. S. and Candia, O. A. (1979). An improved assay for nanomole amounts of inorganic phosphate. Analyt. Biochem. 100, 95-97.

Messersmith, E. K., Leonardo, E. D., Shatz, C. J., TessierLavigne, M., Goodman, C. S. and Kolodkin, A. L. (1995). Semaphorin III can function as a selective chemorepellent to pattern sensory projections in the spinal cord. Neuron 14, 949-959.

Mimikakis, J. L., Nelson, D. L. and Preston, R. R. (1998). Oscillating response to a purine nucleotide disrupted by mutation in Paramecium tetraurelia. Biochem. J. 330, 139-147.

North, R. A. and Barnard, E. A. (1997). Nucleotide receptors. Curr. Opinions Neurobiol. 7, 346-357.

Oka, T., Nakaoka, Y. and Oosawa, F. (1986). Changes in membrane potential during adaptation to external potassium ions in Paramecium caudatum. J. Exp. Biol. 126, 111-117.

Plesner, L. (1995). Ecto-ATPase: Identities and functions. Int. Rev. Cytol. 158, 141-214.

Preston, R. R. and Hammond, J. A. (1998). Long-term adaptation of $\mathrm{Ca}^{2+}$-dependent behavior in Paramecium tetraurelia. J. Exp. Biol. 201, 1835-1846.

Saimi, Y. and Kung, C. (1980). A Ca-induced Na-current in Paramecium tetraurelia. J. Exp. Biol. 88, 305-325.

Scatchard, G. (1949). The attraction of proteins for small molecules and ions. Ann. N.Y. Acad. Sci. 51, 660-674.

Silinsky, E. M. and Gerzanich, V. (1993). On the excitatory effects of ATP and its role as a neurotransmitter in coeliac neurones of the guinea-pig. J. Physiol., Lond. 464, 197-212.

Smith, T. M., Kim, M. Y., Kirley, T. L. and Hennessey, T. M. (1996). Ecto-ATPases of Tetrahymena thermophila: Role in purinergic responses and purification of a soluble form. In Ecto-ATPases: Recent Progress in Structure and Function (ed. L. Plesner, T. L. Kirley and A. F. Knowles), pp. 135-142. New York: Plenum Press.

Smith, T. M., Kirley, T. L. and Hennessey, T. M. (1997). A soluble ecto-ATPase from Tetrahymena thermophila: purification and similarity to the membrane-bound ecto-ATPase of smooth muscle. Arch. Biochem. Biophys. 337, 351-359.

Soto, F., Garciaguzman, M. and Stuhmer, W. (1997). Cloned ligand-gated channels activated by extracellular ATP (P2X receptors). J. Membr. Biol. 160, 91-100.

Valera, S., Hussy, N., Evans, R. J., Adami, N., North, R. A., Surprenant, A. and Buell, G. (1994). A new class of ligand-gated ion channel defined by $\mathrm{P}_{2 \mathrm{X}}$ receptor for extracellular ATP. Nature 371, 516-519.

White, T. D. (1988). Role of adenine compounds in autonomic neurotransmission. Pharmac. Ther. 38, 129-168. 